\title{
KOMPETENSI DPD RI DALAM MENGEMBAN AMANAH UNDANG - UNDANG NOMOR 2 TAHUN 2018 TENTANG MPR, DPR, DPD DAN DPRD SEBAGAI LEMBAGA TINGGI NEGARA
}

\author{
Rianda Dirkareshza \\ Fakultas Hukum, Universitas Pembangunan Nasional "Veteran" Jakarta, Jl. RS, \\ Fatmawati, Kota Jakarta Selatan, 12450, Indonesia \\ E-mail: riandadirkareshza@upnvj.ac.id
}

\begin{abstract}
Abstrak
Salah satu poin penting dalam revisi UU No. 2 Tahun 2018 tentang MPR, DPR, DPD dan DPRD adalah penambahan kewenangan Dewan Perwakilam Daerah Republik Indonesia dalam mengawasi dan mengevaluasi peraturan daerah (perda) dan rancangan peraturan daerah (raperda). Dalam UU MD3 pasal 249 ayat 1 huruf J itu, disebutkan bahwa DPD mempunyai wewenang dan tugas: "melakukan pemantauan dan evaluasi atas rancangan peraturan daerah dan peraturan daerah". Pembentukan DPD sendiri adalah upaya konstitusional untuk mengakomodasi suara daerah dengan memberi saluran, sekaligus peran kepada daerah-daerah. Saluran dan peran tersebut dilakukan dengan memberikan tempat bagi daerah-daerah untuk menempatkan wakilnya dalam badan perwakilan tingkat nasional untuk memperjuangkan dan menyuarakan kepentingan-kepentingan daerahnya, terutama dalam bidang legislasi, anggaran, dan pengawasan. Sehingga akan memperkuat ikatan dalam kesatuan Negara Republik Indonesia. DPD mencerminkan prinsip representasi teritorial atau regional (regional representation) dari daerah, dalam hal ini provinsi. Sama dengan DPD, Keberadaan peraturan perundang-undangan tingkat daerah pada hakikatnya merupakan akibat diterapkannya prinsip desentralisasi dalam penyelenggaraan pemerintahan di daerah. Karena itu memberikan relasi yang cukup terhadap DPD sebagai territorial representative dan perda sebagai regulasi daerah, menjadi syarat bagi jalannya desentralisasi dan pembangunan daerah yang baik.
\end{abstract}

Kata Kunci : DPD RI, Perda, Raperda, Otonomi Daerah, Desentralisasi

\begin{abstract}
One of the important points in the revision of Law No. 2 of 2018 concerning the MPR, $D P R, D P D$ and DPRD is the addition of the authority of the Regional Representative Council of the Republic of Indonesia in supervising and evaluating regional regulations (perda) and draft regional regulations (raperda). In the MD3 Act article 249 paragraph 1 letter $J$, it is stated that the DPD has the authority and duty: "to monitor and evaluate the draft regional regulations and regional regulations". The formation of the DPD itself is a constitutional effort to accommodate the voice of the region by giving channels, as well as the role of the regions. The channel and role is carried out by providing a place for the regions to place their representatives in the national level representative bodies
\end{abstract}


to fight for and voice their regional interests, especially in the areas of legislation, budgeting and supervision. So that it will strengthen ties in the unity of the Republic of Indonesia. The DPD reflects the principle of territorial or regional representation from the region, in this case the province. Same with DPD, the existence of legislation at the regional level is essentially the result of the implementation of the principle of decentralization in the administration of regional governance. Because of that, it provides sufficient relations to the DPD as a territorial representative and a regional regulation as a regional regulation, a condition for the decentralization and good regional development.

Keywords : DPD RI, Regional Regulation, Regional Regulation Draft, Regional Autonomy, Decentralization

\section{A. PENDAHULUAN}

\section{Latar Belakang}

Dewan Per|wakilan Daerah (DPD) adalah Fraksi Utusan Daerah Majelis Permusyawaratan Rakyat (MPR) yang bermetamorfosis menjadi satu lembaga negara baru. Pasal 2 ayat (1) UUD 1945 sebelum amandemen berbunyi: "Majelis Permusyawaratan Rakyat terdiri atas anggota Dewan Perwakilan Rakyat, ditambah dengan utusan-utusan dari daerah-daerah dan golongan-golongan, menurut aturan yang ditetapkan dengan undang-undang." Setelah amandemen menjadi: "Majelis Permusyawaratan Rakyat terdiri atas anggota Dewan Perwakilan Rakyat dan anggota Dewan Perwakilan Daerah yang dipilih melalui pemilihan umum dan diatur lebih lanjut dengan undang-undang." Wacana pembentukan kelembagaan DPD mulai mengemuka pada saat pembahasan susunan dan kedudukan MPR serta susunan mengenai lembaga perwakilan pada BAB VII, dalam rapat ke-2 PAH III BP MPR pada 6 Oktober $1999 .{ }^{1}$ Lembaga ini dimaksudkan sebagai penguat ikatan daerah-daerah dalam wadah Negara

\footnotetext{
${ }^{1}$ Law center - PPUU DPD RI, Peta Jalan Legislasi DPD RI, 2017, Hlm. 17.
} 
Kesatuan Republik Indonesia; mendorong percepatan pembangunan daerah serta mengagregasi aspirasi dan kepentingan daerah dalam perumusan kebijakan nasional. ${ }^{2}$

Pada pasal 22D UUD 1945 menjelaskan ada 3 tupoksi DPD, yaitu: dapat mengajukan Rancangan Undang-Undang (RUU), ikut membahas RUU dan dapat melakukan pengawasan atas pelaksanaan undang-undang (UU). Frasa yang mengaitkan ketiga tupoksi itu adalah otonomi daerah. Secara kasat mata, frasa otonomi daerah menempel pada tiap ayat mengenai tupoksi DPD. Maka secara teoritis dan yuridis antara otonomi daerah dan DPD ada hubungan yang tak dapat dipisahkan. Namun relasi ini sulit ditemukan dalam praktek tata negara kita, kecuali bahwa anggota DPD mewakili daerah provinsi dan setiap waktu tertentu reses ke daerah untuk mendengar aspirasi masyarakat daerah sebagai bentuk kongkrit fungsi representasi lembaga perwakilan.

Praktek ini berbeda dengan relasi antara prinsip negara hukum yang dinormakan dalam amandemen pasal 1 UUD 1945 dengan lembaga bernama Mahkamah Konstitusi (MK). Pasal 1 UUD 1945 mengandung makna bahwa konstitusi merupakan bentuk pelimpahan kedaulatan rakyat (the sovereignity of the people) kepada negara. Dan melalui konstitusi, rakyat membuat statement kerelaan pemberian sebagian hak-haknya kepada negara. Dengan demikian konstitusi harus dikawal dan dijaga dari penyimpangan baik yang dilakukan oleh pemegang kekuasaan maupun aturan hukum di bawah konstitusi. Karena itu pelaksanaan kedaulatan rakyat melalui konstitusi harus dikawal dan dijaga, dan penjagaan konstitusi kemudian diberikan kepada MK. Jimly Asshiddiqie menguraikan:

"Dalam konteks ketatanegaraan, Mahkamah Konstitusi dikonstruksikan sebagai pengawal konstitusi yang berfungsi menegakkan keadilan konstitusional di tengah kehidupan masyarakat. Mahkamah Konstitusi bertugas mendorong dan menjamin agar konstitusi dihormati

\footnotetext{
${ }^{2}$ PPUU DPD RI, Legal Drafting untuk Senator, Hlm. 55.
} 
dan dilaksanakan oleh semua komponen negara secara konsisten dan bertanggungjawab. Di tengah kelemahan sistem konstitusi yang ada, Mahkamah Konstitusi berperan sebagai penafsir agar spirit konstitusi selalu hidup dan mawarnai keberlangsungan bernegara dan bermasyarakat". 3

Ini tidak terjadi dalam hubungan antara DPD dan otonomi daerah. Maka yang terjadi adalah kegamangan dalam menjalankan tugas-tugas konstitusional yang sebenarnya sudah cukup gamblang terdapat dalam UUD 1945. Putusan Mahkamah Konstitusi mengkonfirmasi bahwa DPD adalah lembaga legislative yang peran dan fungsinya tidak boleh dikecilkan oleh lembaga lainnya. DPD harus berperan dalam tiap tahap pembentukan peraturan perundangan yang berkorelasi dengan kewenangannya yaitu otonomi daerah.

Kewenangan dalam memantau dan mengevaluasi legislasi daerah dapat dipandang sebagai kepercayaan baru untuk bagaimana DPD dapat memberikan jalan tengah diantara tarik menarik pemerintah pusat dan pemerintah daerah. Namun patut juga diperhatikan apakah tugas baru tersebut sejalan dengan kewenangan yang harusnya dijalankan menurut UUD 1945 atau sebaliknya bertentangan dengan semangat yang ingin dibawa dari lahirnya DPD.

\section{Rumusan Masalah}

1. Bagaimanakah kewenangan pemantauan dan evaluasi Raperda dan Perda oleh DPD RI menurut peraturan perundangan dan prinsip negara hukum?

2. Bagaimanakah kompetensi DPD RI dalam mengemban amanah Undang Undang Nomor 2 Tahun 2018 Tentang MPR, DPR, DPD dan DPRD sebagai lembaga tinggi negara?

${ }^{3}$ Sekretariat Jenderal MKRI ,Cetak Biru, Membangun Mahkamah Konstitusi, Sebagai Institusi Peradilan Konstitusi Yang Modern Dan Terpercaya, 2004. Hlm. iv. Seperti dikutip oleh Maruarar Siahaan, Hukum Acara Mahkamah Konstitusi Republik Indonesia,..Hlm. 12. 


\section{Metode Penelitian}

Metode penelitian pada dasarnya merupakan rangkaian prosedur tahapan atau cara sistematis yang digunakan untuk mencari kebenaran dalam suatu karya ilmiah dalam hal ini adalah penulisan jurnal, sehingga dapat menghasilkan sebuah jurnal yang berkualitas yaitu jurnal yang memenuhi syarat penelitian. ${ }^{4}$ Jenis penelitian dalam jurnal ini adalah literer atau penelitian perpustakaan (library research), artinya sebuah studi dengan mengkaji buku-buku atau kitab-kitab terkait dengan jurnal ini yang berasal dari perpustakaan (bahan pustaka). Semua sumber berasal dari bahan-bahan tertulis (cetak) yang berkaitan dengan permasalahan penelitian dan literatur-literatur lainnya (elektronik). ${ }^{5}$

Pendekatan dalam penelitian dibedakan menjadi dua, yaitu pendekatan kualitatif dan pendekatan kuantitatif. Dalam penulisan jurnal ini pendekatan yang digunakan adalah pendekatan kualitatif, yaitu pendekatan yang dalam pengolahan dan analisa data tidak menggunakan angka-angka, simbol dan atau variable matematis melainkan dengan pemahaman mendalam (in depth analysis). Dalam pembahasannya peneliti menggunakan pendekatan yuridis- normatif, yaitu jenis pendekatan dengan menggunakan ketentuan perundang-undangan yang berlaku pada suatu Negara atau metode pendekatan hukum doktrinal yaitu teori-teori hukum dan pendapat para ilmuwan hukum terutama yang berkaitan dengan permasalahan yang dibahas. ${ }^{6}$ Pendekatan yuridis-normatif yang digunakan dalam penelitian ini adalah pendekatan melalui hukum positif, yaitu menelaah aturan-aturan hukum positif untuk menemukan legalitas kewenangan baru DPD RI

\footnotetext{
${ }^{4}$ Soemitro, Metodologi Penelitian Hukum, (Jakarta: Rineka Cipta, 1990), Hlm. 10.

${ }^{5}$ Sutrisno Hadi, Metodologi Riserch 1 (Yogyakarta: Gajah Mada, 1980), Hlm. 3

${ }^{6}$ Soemitro, Metodologi Penelitian Hukum dan Jurimetri, (Jakarta: Ghalia Indonesia, 1998), Hlm.
} 24. 
dalam rangka memantau dan mengevaluasi Raperda dan Perda. Selain itu menelaah bagaimana DPD melaksanakan kewenangan itu.

Penulisan jurnal ini bersumberkan pada sumber bahan penelitian primer dan sumber bahan penelitian sekunder, yaitu: ${ }^{7}$

1. Bahan Hukum Primer yaitu bahan-bahan hukum yang mengikat ${ }^{8}$ seperti UUD 1945; UU MPR, DPR, DPD dan DPRD (UU MD3); UU No. 12 tahun 2011 tentang Pembentukan Peraturan Perundangan; Peraturan DPD RI No. 3 tahun 2018 tentang Tata Tertib dan UU Pemerintahan Daerah.

2. Bahan hukum Sekunder yang memberikan penjelasan mengenai bahan hukum primer, seperti Naskah Akademik. Rancangan Undang-Undang, hasil penelitian, atau pendapat para pakar hukum.

3. Ketiga, Bahan hukum tersier yang memberikan petunjuk maupun penjelasan terhadap bahan hukum primer dan sekunder seperti kamus dan ensiklopedia. ${ }^{9}$

Adapun bahan lain yang menjadi objek penelitian adalah Buku dan Perundangan tentang Hukum Tata Negara, Politik Hukum, Pemda dan Otonomi Daerah. Selain itu untuk melengkapi data dan informasi, perlu juga penulis mewawancara pihak-pihak yang terkait dengan tema penulisan jurnal ini.

\section{B. HASIL \& PEMBAHASAN}

1. Kewenangan Pemantauan Dan Evaluasi Raperda Dan Perda Oleh Dpd Ri Menurut Peraturan Perundangan Dan Prinsip Negara Hukum

7 Suharsimi Arikunto, Prosedur Penelitian suatu Pendekatan Praktek (Jakarta: Rineka Cipta,2000), Hlm. 234.

${ }^{8}$ Soerjono Soekanto, Pengantar Penelitian Hukum, UI-Press, Jakarta, Hlm. 52.

${ }^{9}$ Amiruddin dan Zainal Asikin, Pengantar Metode Penelitian Hukum, PT. Raja Grafindo, Jakarta, 2006, Hlm. 31-32. 
Seperti yang telah disebutkan dalam bab terdahulu, DPD adalah lembaga perwakilan representasi territorial yang lahir dengan semangat mengagregasi kepentingan daerah di tingkat nasional. Membagi kekuasaan pemerintahan dengan prinsip otonomi dan desentralisasi, tidak serta merta menyelesaikan persoalan yang terjadi antara pusat dan daerah ini. Kewenangan pemantauan dan evaluasi legislasi daerah yang diberikan lewat amandemen UU MD3 patut kita lihat secara lebih dalam dari sisi konstitusional dan peraturan perundangan.

Suatu negara disebut negara kesatuan apabila kekuasaan hanya dipegang oleh pemerintah pusat, sementara provinsi-provinsi menerima kekuasaan dari pemerintah pusat, dan provinsi-provinsi tersebut tidak mempunyai hak mandiri. ${ }^{10}$ Dalam negaranegara dengan bentuk negara kesatuan (unitary state), ditinjau dari sudut pembagian kewenangan, terdapat dua kewenangan/urusan pemerintah yakni yang tersentralisasi dan kewenangan/urusan pemerintah yang didesentralisasikan. ${ }^{11}$ Urusan yang didesentralisasikan dalam negara kesatuan bukan bersifat ketatanegaraan, melainkan hanya urusan pemerintahan. Hal tersebut terutama berdasarkan pendapat C.F. Strong yang mengatakan bahwa kekuasaan apapun yang dimiliki berbagai distrik di dalam wilayah yang dikelola sebagai suatu keseluruhan oleh pemerintah pusat harus diselenggarakan menurut kebijakan pemerintah itu. ${ }^{12}$ Walaupun memungkinkan bagi setiap satuan pemerintahan daerah untuk membentuk suatu peraturan sendiri, namun tertib hukum menghendakinya supaya tidak bertentangan dengan kebijakan pemerintah itu atau disebut

\footnotetext{
${ }^{10}$ Tim Penyusun, Otonomi atau Federalisme, dampaknya terhadap Perekonomian, Pustaka Sinar Harapan, Harian Suara Pembaharuan, Jakarta, 2000, Hlm. 14.

11 Nicole Niessen, Municipal Government In Indonesia Policy, law and Practice of Decentralization and Urban Planning, Research School CNWS School of Asian, African, and Amerindian Studies, Universitiet Leiden, The Netheralands, 1999, Hlm.21

12 C.F. Strong, Konstitusi-Konstitusi Politik Modern: Studi Perbandingan tentang Sejarah dan Bentuk-Bentuk Konstitusi di Dunia, Nusamedia, Bandung, Cetakan Kedua, 2008, Hlm. 87.
} 
peraturan yang lebih tinggi. Keharusan tersebut sejalan dengan ciri negara hukum klasik yang salah satunya adalah terdapat jaminan hak asasi manusia, pemencaran kekuasaan negara/pemerintah, dan kekuasaan pemerintahan harus didasarkan atas hukum. ${ }^{13}$ Dengan kekurangpuasan terhadap jaminan HAM yang hanya terhadap hak sipil dan politik, kemudian berkembang kepada hak-hak asasi sosial. ${ }^{14}$ Perkembangan jaminan inilah yang sejalan dengan paradigma negara kesejahteraan, yang menghendaki campur tangan negara dalam berbagai bidang kehidupan untuk kesejahteraan rakyat. Pemencaran kekuasaan yang demikian dipandang sebagai wujud pengakuan kemajemukan.

Dengan demikian desentralisasi merupakan bagian dari upaya demokratisasi. Walaupun bukan berarti dalam suasana sentralistis kedaulatan rakyat tidak terwujud, menurut Bagir Manan ${ }^{15}$, desentralisasi merupakan cara terbaik untuk mewujudkan kedaulatan rakyat. Dikatakan demikian dengan alasan bahwa desentralisasi memperluas kesempatan bagi rakyat baik kualitatif maupun kuantitatif turut serta memikul tanggung jawab penyelenggaraan pemerintahan dibanding kalau hanya sebatas pada penyelenggaraan pada tingkat Pusat. Dengan paradigma negara kesejahteraan, satuan pemerintahan yang terendah adalah ujung tombak dari upaya menghantarkan kesejahteraan rakyat. Dengan demikian dapat dikatakan bahwa desentralisasi bertujuan untuk menghantarkan kepada demokratisasi, dan kesejahteraan rakyat melalui kedekatan pelayanan publik.

Dari berbagai pendapat para ahli mengenai desentralisasi, ${ }^{16}$ dapat diamati beberapa hal. Pertama, pengertian desentralisasi yang agak sempit sebagaimana

\footnotetext{
${ }^{13}$ Bagir Manan, Hubungan Pusat....., op.cit., Hlm. 35.

${ }^{14}$ Ibid., Hlm. 37-38.

15 Ibid., Hlm. 34-35.

${ }^{16}$ Ibid., Hlm. 20-25.
} 
dikemukakan oleh Van Der Pot yang hanya mengklasifikasikan desentralisasi menjadi dua jenis yakni desentralisasi teritorial dan desentralisasi fungsional. Koesoemahatmadja juga termasuk dalam kategori yang membagi desentralisasi agak sempit karena menurutnya desentralisasi terbagi atas dekonsentrasi dan desentralisasi ketatanegaraan. Kedua, pengertian desentralisasi yang lebih luas dari kategorisasi yang disampaikan oleh Van Der Pot dan Koesoemahatmadja. Dalam kategori kedua ini dijumpai pembagian desentralisasi yang disampaikan oleh Amrah Muslimin dan Irawan Soejito. Selain desentralisasi teritorial dan fungsional, juga terdapat desentralisasi administratif atau dekonsentrasi. Amrah Muslimin selain membagi kedalam desentralisasi teritorial dan fungsional juga memasukkan desentralisasi kebudayaan. Berbeda dengan kedua ahli lainnya, Amrah Muslimin tidak memasukkan dekonsentrasi sebagai salah satu bentuk desentralisasi. Ketiga, pengertian desentralisasi yang lebih sempit dari yang dijelaskan oleh para ahli di atas yakni pengertian desentralisasi menurut UU No. 23/2014. Pasal 1 angka 7 menyatakan bahwa Desentralisasi adalah penyerahan Urusan Pemerintahan oleh Pemerintah Pusat kepada daerah otonom berdasarkan Asas Otonomi.

Berdasarkan UUD 1945 pengaturan pemerintahan daerah dijumpai dalam Pasalpasal 18, 18A dan 18B. pemerintahan daerah diselenggarakan berdasarkan prinsipprinsip sebagai berikut: pertama, Prinsip daerah mengatur dan mengurus sendiri urusan pemerintahan menurut asas otonomi dan tugas pembantuan sebagaimana diatur dalam Pasal 18 ayat (2) UUD 1945. ${ }^{17}$ Kedua, Prinsip menjalankan otonomi seluas-luasnya yang diatur dalam Pasal 18 ayat (5) UUD 1945. ${ }^{18}$ Ketiga, Prinsip kekhususan dan keragaman

\footnotetext{
${ }^{17}$ Bagir Manan, Menyongsong Fajar ..., op.cit., Hlm. 8-9. $\pi$

18 Bagir Manan, Perjalanan Historis Pasal 18, UNSIKA, Karawang, 1993, hlm 21, dan Bagir Manan, Menyongsong Fajar Otonomi Daerah, Pusat Studi Hukum Fakultas Hukum UII, Yogyakarta, 2001, hlm 12.
} 
daerah sebagaimana diatur dalam Pasal 18 ayat (1) UUD 1945. ${ }^{19}$ keempat, prinsip mengakui dan menghormati kesatuan masyarakat hukum adat beserta hak-hak tradisionalnya sebagaimana diatur dalam Pasal 18B ayat (2) UUD 1945. ${ }^{20}$ Kelima, prinsip mengakui dan menghormati pemerintahan daerah yang bersifat khusus dan istimewa sebagaimana diatur dalam Pasal 18B ayat (1) UUD 1945. ${ }^{21}$ Keenam, Prinsip badan perwakilan dipilih langsung dalam suatu pemilihan umum sebagaimana diatur dalam Pasal 18 ayat (3) UUD 1945. ${ }^{22}$ Ketujuh, prinsip hubungan pusat dan daerah harus dilaksanakan secara selaras dan adil sebagaimana terdapat dalam Pasal 18A ayat (2) UUD 1945.23

Sementara itu pengaturan mengenai DPD diatur secara spesifik dalam pasal 22C dan 22D. Walau memang tidak ada terlihat hubungan langsung dalam prosedur pemerintahan daerah tadi dengan DPD, otonomi daerah menjadi kata kunci yang menjelaskan mengenai peran dan fungsi DPD RI. Bahkan dalam menderifasi RUU yang menjadi kewenangan DPD RI untuk diajukan kepada DPR, DPD mendasarkannya pada UU Pemerintahan Daerah yang memberikan batasan urusan pemerintah apa saja yang merupakan otonomi daerah.

Frasa Pemantauan dan Evaluasi secara bersamaan terdapat dalam Pasal 368 UU Pemda: “(1) Gubernur sebagai wakil Pemerintah Pusat melakukan pemantauan dan evaluasi terhadap kerja sama yang dilakukan Daerah Kabupaten/Kota dalam satu DaerahProvinsi. (2). Menteri melakukan pemantauan dan evaluasi terhadap kerja sama antar-Daerah provinsi, antara Daerah provinsi dan Daerah kabupaten/kota di wilayahnya,

\footnotetext{
${ }^{19}$ Bagir Manan, Menyongsong Fajar ..., op.cit., Hlm. 12-13.

${ }^{20}$ Ibid., Hlm. 13.

${ }^{21}$ Ibid., hlm 15-16.

22 Ibid.

${ }^{23}$ Ibid., hlm 17.
} 
serta antara Daerah provinsi dan Daerah kabupaten/kota di luar wilayahnya. Dalam Permendagri No 80 tahun 2015, pasal 159 ayat (1) disebutkan:

"Direktur Jenderal Otonomi Daerah, Direktur Jenderal Bina Keuangan Daerah, Direktur Jenderal Bina Pembangunan Daerah atas nama Menteri Dalam Negeri melakukan pemantauan terhadap tindaklanjut hasil evaluasi dan pembatalan perda provinsi dan peraturan gubernur.'

Dalam ayat berikutnya dari pasal 159 permendagri tersebut menjelaskan juga bahwa Gubernur melakukan pemantauan terhadap tindak lanjut hasil evaluasi dan pembatalan perda Kota dan Kabupaten. Pemantauan dilakukan setelah evaluasi - yang termasuk dalam proses fasilitasi - selesai dilakukan. Fasilitasi menurut Permendagri adalah tindakan pembinaan berupa pemberian pedoman dan petunjuk teknis, arahan, bimbingan teknis, supervisi, asistensi dan kerja sama serta monitoring dan evaluasi yang dilakukan oleh Menteri Dalam Negeri kepada provinsi serta Menteri Dalam Negeri dan/atau gubernur kepada kabupaten/kota terhadap materi muatan rancangan produk hukum daerah berbentuk peraturan sebelum ditetapkan guna menghindari dilakukannya pembatalan. Sedangkan evaluasi adalah pengkajian dan penilaian terhadap rancangan perda yang diatur sesuai Undang-Undang di bidang pemerintahan daerah dan peraturan perundangundangan lainnya untuk mengetahui bertentangan dengan kepentingan umum, dan/atau peraturan perundangundangan yang lebih tinggi.

Sementara, secara terpisah frasa evaluasi terdapat pada pasal Pasal 245 UU Pemda yang berbunyi :

"Rancangan Perda Provinsi yang mengatur tentang RPJPD, $R P J M D, A P B D$, perubahan $A P B D$, pertanggungjawaban pelaksanaan $A P B D$, pajak daerah, retribusi daerah dan tata ruang daerah harus mendapat evaluasi Menteri sebelum ditetapkan oleh gubernur".

Frasa pemantauan ini kemudian dimasukkan secara bulat dan bersamaan dalam wewenang dan tugas DPD yang terdapat dalam UU MD3 yaitu: melakukan pemantauan 
dan evaluasi atas rancangan peraturan daerah dan peraturan daerah. ${ }^{24}$ Dalam Tatib DPD No. 3 tahun 2018, yang direvisi berkaitan revisi UU MD3, tugas pemantauan ini kemudian dilakukan dengan cara: ${ }^{25}$

1. pengumpulan data untuk mendapatkan informasi rancangan Perda dan Perda provinsi, kabupaten, dan kota;

2. rapat kerja dengan pemerintah daerah dan/atau DPRD provinsi, kabupaten, dan kota, termasuk pemangku kepentingan di daerah; dan

3. kunjungan kerja ke pemerintah daerah dan/atau DPRD provinsi, kabupaten, dan kota, termasuk pemangku kepentingan di daerah.

Dan frasa evaluasi dijelaskan dalam pasal Pasal 242 Tatib DPD: "Evaluasi rancangan Perda dan Perda sebagaimana dimaksud dalam Pasal 239 ayat (3) meliputi analisis rancangan Perda dan Perda provinsi, kabupaten, dan kota”.

Kemendagri melakukan eksekutif review dan Mahkamah Agung melakukan yudisial riview. Putusan MK No. 137/PUU-XIII/2015 sebenarnya telah menganulir kewenangan Menteri untuk membatalkan Perda. Dalam pertimbangannya, MK menyebutkan bahwa:

"Menurut Undang-Undang Nomor 12 Tahun 2011 tentang Pembentukan Peraturan Perundang-undangan (UU 12/2011), Perda jelas disebut sebagai salah satu bentuk peraturan perundang-undangan dengan hierarki di bawah Undang- Undang. Sepanjang suatu norma hukum dituangkan dalam bentuk peraturan sebagaimana dimaksud dalam $U U$ 12/2011 tersebut, dan tingkatannya berada di bawah undang-undang, maka sebagaimana ditentukan oleh Pasal 24A ayat (1) UUD 1945, pengujiannya hanya dapat dilakukan oleh Mahkamah Agung, bukan oleh lembaga lain. Demikian pula penegasan dalam Pasal 9 ayat (2) UU 12/2011 yang menentukan, "Dalam hal suatu peraturan perundangundangan di bawah Undang-Undang diduga bertentangan dengan Undang-Undang, pengujiannya dilakukan oleh Mahkamah Agung".

\footnotetext{
24 Tatib DPD No. 3 tahun 20018 tentang Tatib, Pasal 5 ayat 1 huruf j.

${ }^{25}$ Ibid, Pasal 240
} 
Dalam perspektif negara kesatuan (unitary state, eenheidsstaat) adalah logis untuk mengembangkan pengertian bahwa pemerintahan atasan berwenang melakukan kontrol terhadap unit pemerintahan bawahan. Artinya, pemerintahan pusat dalam konteks NKRI berdasarkan UUD 1945 tentu dapat dikatakan mempunyai kewenangan untuk mengontrol unit-unit pemerintahan daerah provinsi ataupun pemerintahan daerah kabupaten dan kota. Demikian pula pemerintahan daerah provinsi juga dapat diberi kewenangan tertentu dalam rangka mengendalikan jalannya pemerintahan daerah kabupaten dan kota di bidang pengaturan. Yang dikendalikan atau dikontrol oleh pemerintahan atasan itu antara lain misalnya melalui kewenangan untuk melakukan "executive abstract preview", bukan mekanisme "review" atas peraturan daerah yang sudah berlaku mengikat untuk umum. Oleh karena itu, terhadap peraturan daerah sebagai produk legislatif di daerah, sebaiknya hanya di "preview" oleh pemerintahan atasan apabila statusnya masih sebagai rancangan peraturan daerah yang belum mengikat untuk umum. Jika peraturan daerah itu sudah mengikat umum, maka sebaiknya yang mengujinya adalah lembaga peradilan sebagai pihak ketiga yang sama sekali tidak terlibat dalam proses pembentukan peraturan daerah yang bersangkutan sesuai dengan sistem yang dianut dan dikembangkan menurut UUD 1945 yakni "centralized model of judicial review", bukan "decentralized model", seperti ditentukan dalam Pasal 24A ayat (1) dan Pasal 24C ayat (1) UUD 1945.

Jika melihat putusan dan pertimbangan ini, DPD sebenarnya sudah dapat menentukan harus berada di posisi mana dalam hal kewenangan pemantauan dan evaluasi perda ini. Walaupun DPD tidak ikut dalam proses pembentukan perda, namun DPD dan DPRD berada dalam satu rumpun kewenangan legislasi. Bahkan pengaturan soal tugas dan wewenangnya berada dalam satu Undang-Undang yaitu UU MD3. Dengan bahasa 
lain, suatu produk hukum hanya absah jika diuji melalui institusi hukum bernama pengadilan. Ini adalah nafas utama negara hukum sebagaimana diajarkan pula dalam berbagai teori pemencaran (distribution of power) dan pemisahan kekuasaan (separation of power) yang berujung pada pentingnya mekanisme saling mengawasi dan mengimbangi (checks and balances).

Sebagaimana MK membatalkan kewenangan menteri untuk membatalkan Perda, maka besar kemungkinan untuk kewenangan pemantauan perda dan raperda DPD ini juga dapat dianggap bertentangan dengan UUD 1945. Karena perda adalah produk perundangan yang sifatnya mengatur dan tidak dapat diuji atau dievaluasi oleh pihak yang terlibat dalam pembuatan perundangan itu. Pemantauan dan evaluasi dapat dilakukan jika peraturan itu belum diundangkan dan masih bersifat rancangan peraturan daerah. Kecuali kemudian dalam perumusan lanjutan mengenai pelaksanaan kewenangan pemantauan dan evaluasi perda ini, DPD tidak masuk dalam proses pembatalan, tapi hanya sebatas memberikan masukan kepada lembaga yudikatif. Dan jika begitu maka pemberian kewenangan baru ini terasa equal dengan kewenangan legislasi DPD yang hanya dapat mengusulkan RUU kepada DPR tanpa dapat memutuskan.

Analisa diatas didapat jika memahami frasa evaluasi menurut UU Pemda, dimana digunakan Pemerintah Pusat untuk membatalkan legislasi yang dihasilkan oleh daerah. Jika kita lihat frasa pemantauan dan evaluasi dalam pengertian yang lebih umum, maka ini sejalan dengan fungsi pengawasan fungsi representasi yang dimiliki oleh DPD. Pasal 22 D ayat (3) menyebutkan bahwa DPD dapat melakukan pengawasan atas pelaksanaan undang-undang mengenai: otonomi daerah, hubungan pusat dan daerah, pembentukan dan pemekaran serta penggabungan daerah, pengelolaan sumber daya alam dan sumber daya ekonomi lainnya, pelaksanaan anggaran pendapatan dan belanja negara, pajak, 
pendidikan, dan agama serta menyampaikan hasil pengawasannya itu kepada DPR sebagai bahan pertimbangan untuk ditindaklanjuti. Pengawasan atas pelaksanaan UU bukan hanya berarti mengawasi penerapan satu undang-undang tetapi juga melihat bagaimana satu UU diturunkan secara baik ke dalam peraturan perundangan dibawahnya, termasuk perda. Asumsi ini terlalu umum dan terlalu argumentatif untuk dijadikan sandaran atas pemberian wewenang pengawasan perda. Karena kalau ini menjadi alasan, maka kewenangan tadi menjadi tidak relevan dan tentu saja hal ini tidak sejalan dengan positivisme hukum.

\section{Legislative Review}

Di Negara kita, proses pembentukan peraturan perundang-undangan dilakukan oleh beberapa lembaga yang berbeda-beda: UUD NRI 1945 dibuat oleh Majelis Permusyawaratan Rakyat (MPR); ${ }^{26}$ Undang-Undang dibuat oleh DPR bersama Presiden dan DPD; ${ }^{27}$ Peraturan Pemerintah Pengganti Undang-Undang dibuat oleh Presiden dalam kegentingan yang memaksa; ${ }^{28}$ Peraturan-Pemerintah dibuat oleh pemerintah sebagai pelaksana dari undang-undang;, ${ }^{29}$ Peraturan Presiden dibuat oleh Presiden. ${ }^{30}$ Peraturan Daerah Tigkat Provinsi dibuat oleh DPRD provinsi bersama Gubernur. ${ }^{31}$ Peraturan Daerah Kabupaten/Kota dibuat oleh DPRD Kabupaten/Kota bersama Bupati atau Wali kota. ${ }^{32}$

Bermacam lembaga dan tingkatan kewenangan pembentuk peraturan perundangan ini membutuhkan jaminan tidak tumpang tindih atau berbenturan satu sama

\footnotetext{
${ }^{26}$ Pasal 3 Ayat 1 UUD NRI 1945

${ }^{27}$ Pasal 20 ayat 1 danpasal 5 UUD NRI 1945

${ }^{28}$ Pasal 22 UUD NRI 1945

${ }^{29}$ Pasal 5 Ayat 2 UUD NRI 1945

${ }^{30}$ Pasal 55 UU No. 12 Tahun 2011 Tentang Pembentukan Peraturan Perundang-undangan

${ }^{31}$ Pasal 56 UU No. 12 Tahun 2011 TentangPembentukanPeraturanPerundang-undangan

${ }^{32}$ Pasal 63 UU No. 12 Tahun 2011 TentangPembentukanPeraturanPerundang-undangan
} 
lain. Hal ini penting karena pada hakikatnya peraturan perundang-undangan yang terwujud dalam berbagai rupa tersebut merupakan satu kesatuan nilai. ${ }^{33}$ Artinya, antara peraturan perundang-undangan dari paling atas sampai dengan yang paling bawah merupakan satu kesatuan atau memiliki hubungan yang tidak bisa dipisahkan. Peraturan perundang-undangan yang paling tinggi harus menjadi sumber bagi peraturan perundangundangan yang lebih rendah. Penyimpangan isi oleh peraturan perundang-undangan yang lebih rendah terhadap peraturan perundang-undangan yang lebih tinggi adalah sesuatu yang tidak dapat dibenarkan dalam stubenfau theory. Sebab, penyimpangan jenis ini akan membuat satu kesatuan nilai yang terkandung dalam hierarki peraturan perundangundangan selain menjadi terabaikan juga akan membuat ketidakteraturan dalam tata peraturan perundang-undangan dalam sebuah negara. Potensi ini terjadi dalam konteks pembentukan peraturan perundang-undangan di Indonesia mengingat pembentuk peraturan perundang-undangan yang bermacam-macam. Bermacam-macamya lembaga yang memiliki kewenangan untuk membentuk peraturan peraturan perundang-undangan tentu membuka potensi tidak selarasnya antara satu peraturan perundang-undangan dengan peraturan perundang-undangan lainnya. Hal ini tidak lepas karena tiap-tiap lembaga pembentuk tersebut memiliki berbagai perbedaan. Pertama; masing-masing lembaga pembentuk peraturan perundang-undangan tersebut berpotensi memiliki perbedaan tafsir terhadap subtansi dari norma peraturan perundang-undangan sehingga peraturan perundang-undangan yang lebih tinggi bisa dimaknai berbeda di peraturan perundang-undangan yang berada dibawahnya sehingga acapkali peraturan perundang-

\footnotetext{
${ }^{33}$ Safi'i, Integrasi kewenangan Pengujian peraturan perundang-undangan Oleh Lembaga Peradilan (Judicial Review) di Indonesia. Malang, PDIH-UB.
} 
undangan yang lebih rendah bertentangan dengan peraturan perundang-undangan yang lebih tinggi.

Kedua: tiap-tiap lembaga pembentuk peraturan perundang-undangan memiliki kepentingan masing-masing (conflick of interest) sehingga selalu berupaya memenangkan kepentingannya masing-masing dan melupakan subtansi peraturan perundang-undangan yang berada di atasnya. Landasan memberikan kewenangan membentuk peraturan perundang-undangan atas peraturan yang lebih tinggi adalah supaya dapat memperjelas subtansi dari peratuan perundang-undangan yang lebih tinggi. Akan tetapi hal ini seringkali diabaikan oleh lembaga yang memiliki kewenangan untuk membentuknya.

Ketiga: kompromi politik. tiap lembaga pembentuk peraturan perundangundangan merupakan lembaga yang sarat dengan kepentingan politik. Salah satu yang sangat kental adalah adanya kompromi politik. Dalam lembaga politik yang juga memiliki kewenangan untuk membentuk peraturan perundang-undangan, Kompromi politik merupakan sebuah fenomena yang sudah lumrah. Kompromi politik ini terjadi karena masing-masing kelompok politik yang terdapat dalam lembaga tersebut merasa bahwa untuk mencapai kepentingan tertentu terutama kepentingan kelompok harus berkompromi dengan kelompok lain. Ketika kompromi politik terjadi pada proses pembentukan peraturan perundang-undangan, yang ada bukan kompromi untuk subtansi peraturan perundang-undangan yang tepat atas peraturan perundang-undangan yang lebih tinggi. Kompromi politik acapkali melarikan maksud dari peraturan perundang-udangan yang lebih tinggi. Pada konteks ini, dapat dilihat dari banyaknya peraturan perundangundangan khususnya undang-undang yang bertentangan dengan isi UUD Tahun 1945. DPR selaku pembentuk peraturan perundang-undangan seringkali melakukan kompromi 
politik saat melahirkan undang-undang dan mengaburkan tujuan dari subtansi UUD Tahun 1945. DPR RI lebih memprioritaskan kepentingan politiknya ketimbang kepentingan bangsa yang termuat dalam UUD NRI 1945. Dalam mencegah penyimpangan makna dari peraturan perundang-undangan yang lebih rendah atas peraturan perundang-undangan yang lebih tinggi maka asas yang dianut dalam hukum positif Indonesia dalah lex superiory derogat lex inferiory. Peraturan perundangundangan yang lebih rendah tidak boleh bertentangan baik secara materil maupun formil atas peraturan perundang-undangan.

Dari asas di atas, maka posisi hierarkis suatu peraturan perundang-undangan sangatlah strategis. Semakin tinggi suatu jenis peraturan perundang-undangan maka semakin signifikan peraturan perundang-undangan tersebut mempengaruhi hukum suatu negara. Oleh karenanya, jenis peraturan perundang-undangan yang menempati posisi teratas harus benar-benar sesuai dengan cita hukum suatu negara. Dalam konteks ke Indonesian dengan berdasarkan pada ketentuan hierarki peraturan perundang-undangan sebagaimana diatur dalam pasal 7 ayat (1) UU nomor 12 Tahun 2011 tentang pembentukan peraturan perundang-undangan maka posisi peraturan perundangundangan yang amat strategis adalah peraturan perundang-undangan yang dibentuk oleh lembaga legislatif. Yakni UUD tahun 1945dan Undang-Undang.

Dengan demikian maka harus dipastikan bahwa peraturan perundang-undangan yang kekuasaan membentuknya ada pada lembaga legislatif tersebut harus benar-benar sesuai dengan kehendak dan logika rakyat. Kesalahan pada level peraturan perundangundangan yang dibentuk oleh lembaga legislatif tentu akan berimplikasi langsung terhadap keresahan masyarakat di Indonesia. Mengingat kesalahan pada level peraturan perundang-undangan yang dibentuk oleh lembaga legislatif akan membuat peraturan 
perundang-undangan dibawahnya atau peraturan perundang-undangan delegasi. Sebab peraturan delegasi berfungsi sebagai peraturan pelaksana seperti kehadiran Perda adalah peraturan pelaksana atas terbitnya suatu undang-undang.

Dalam praktik selama ini, banyak dijumpai undang-undang yang dibentuk oleh lembaga legislatif yang tidak mencerminkan kehendak dan logika rakyat dan cenderung lari dari nalar keadilan warga negara Indonesia. Untuk itu, mekanisme pengujian atas peraturan perundang-undangan menjadi penting dilakukan. Alasannya adalah dalam rangka menjaga kedaulatan rakyat mengingat pelaksanaan kedaulatan rakyat Indonesia yang dilaksanakan berdasarkan UUD maka UUD dan peraturan perundang-undangan yang berada dibawahnya, harus dapat diuji oleh warga negara Indonesia apakah isinya sesuai dengan kehendak rakyat atau sebaliknya. Kemudian juga mencegah pembentuk peraturan perundang-undangan supaya tetap berada dalam koridornya. Tidak dapat dipungkiri, para legislator atau pembentuk peraturan perundangan masih mengalami berbagai persoalan selain persoalan kompetensi yang diragukan juga persoalan politis. Persoalan inilah yang menyebabkan para pembentuk undang-undang tidak bekerja berdasarkan asas-asas pembentukan undang-undang yang baik. ${ }^{34}$

Jenis pengujian yang marak dilakukan adalah mekanisme pengujian materi melalui pengadilan yakni judicial review baik kepada Mahkamah Agung (MA) maupun Mahkamah Konstitusi (MK). Pengujian kepada dua lembaga ini bisa berupa pengujian materil maupun pengujian formal. Pengujian secara materil ialah pengujian apakah suatu peraturan perundang-undangan bertentangan dengan peraturan perundang-undangan yang berada di atasnya atau tidak. Pengujian secara formal adalah pengujian apakah suatu

\footnotetext{
${ }^{34}$ Ahmad Siboy, Pengujian Undang-Undang. Malang. Jurnal Negara dan Keadilan.
} 
peraturan perundnag-undnagan telag dibentuk sesuai dengan prosedur yang berlaku terutama terkait dengan lembaga yang berwenang membentuk.

Terlepas dari mekanisme pengujian materi oleh lembaga yudikatif (judicial review) yang dominan dalam menghadapi permasalahan dalam peraturan perundangundangan, dalam kaitan dengan tesis ini, sebenarnya masih ada dua mekanisme pengujian peraturan perundang-undangan yang dapat ditempuh yakni mekanisme pengujian oleh lembaga eksekutif dan legislatif. Mekanisme pengujian oleh lembaga eksekutif adalah mekanise pengujian yang dilakukan oleh pemerintah. Seperti sudah disampaikan di bab sebelumnya, mekanisme ini berlaku atas peraturan daerah yakni peraturan daerah Provinsi dan peraturan daerah Kabupaten dan Kota. Pasal 251 UU nomor 09 tahun 2015 tentang perrubahan kedua atas undang-undang nomor 23 tahun 2014 tentang pemerintahan daerah berbunyi:

"Perda Provinsi dan peraturan gubernur yang bertentangan dengan ketentuan peraturan perundang-undangan yang lebih tinggi, kepentingan umum, dan/atau kesusilaan dibatalkan oleh Menteri."

Sedangkan kewenangan membatalkan peraturan di tingkat kabupaten/kota diatur pada Pasal 251 ayat 3 yang Berbunyi:

"Dalam hal gubernur sebagai wakil Pemerintah Pusat tidak membatalkan Perda Kabupaten/Kota dan/atau peraturan bupati/wali kota yang bertentangan dengan ketentuan peraturan perundang-undangan yang lebih tinggi, kepentingan umum, dan/atau kesusilaan sebagaimana dimaksud pada ayat (2), Menteri membatalkan Perda Kabupaten/Kota dan/atau peraturan bupati/wali kota." 35

Dengan ketentuan di atas maka seorang Gubernur dapat membatalkan suatu peraturan daerah Kabupaten dan Kota bilamana mendapati peraturan daerah Kabupaten dan Kota tersebut bertentangan dengan peraturan daerah Provinsi. Menteri dalam negeri juga dapat membatalkan peraturan daerah Provinsi bilamana mendapati peraturan daerah

\footnotetext{
${ }^{35}$ Pasal 251 UU 23 Tahun 2014 tentang Pemerintahan Daerah.
} 
Provinsi yang bertentangan dengan peraturan perundang-undangan yang berada di atasnya. Kewenangan pembatalan eksecutive riview ini kemudian diuji materi ke Mahkamah Konstitusi. Dalam putusannya, MK kemudian membatalkan kewenangan lembaga eksekutif membatalkan produk perundangan yang dibentuk oleh lembaga legislatif.

Legislative Review adalah mekanisme pengujian yang dilakukan oleh lembaga legislatif. Dalam mekanisme ini, lembaga legislatiflah yang melakukan proses uji materi atas suatu peraturan perundang-undangan. Dalam konteks ke Indonesian, mekanisme ini tidak begitu jelas bentuk atau rupanya. Sebab, yang marak dalam praktek peraturan perundang-undangan yang ada di Indonesia, lembaga legislatif tidak mempermanenkan dan memperjelas mekanisme pengujian oleh lembaga legislatif. Lembaga legislatif biasanya langsung merubah atau merevisi suatu peraturan perundang-undangan bukan mengujinya. Artinya, legislative review seakan dianggap sama prosesnya dengan perubahan atau revisi peraturan perundang-undangan yang selama ini dilakukan oleh lembaga legislatif padahal sesungguhnya antara perubahan peraturan perundangundangan dengan proses pengujian peraturan perundang-undangan memiliki perbedaan. Perubahan atau revisi atas suatu peraturan perundang-undangan yang dilakukan oleh lembaga legislatif tidak dapat dikatakan sebagai pengujian oleh lembaga legislatif sebab hal tersebut merupakan bagian dari kekua

saan membentuk yang dimiliki oleh lembaga legislatif. Dalam proses melakukan perubahan atas suatu peraturan perundang-undangan yakni undang-undang, lembaga legislatif tidak dapat dikatakan melakukan pengujian sebab dalam proses perubahan tersebut anggota legislatif tidak menguji suatu peraturan perundang-undangan yang akan di rubah. Bagi lembaga legislatif sendiri memang sulit untuk mempratekkan legislative 
review. Sebab akan sangat sulit bagi mereka melakukan pengujian atas peraturan undangundang yang mereka bentuk sendiri.

Kalaupun lembaga legislatif di Indoensia tidak akrab dengan legislative review, sebenarnya ada satu mekanisme pengujian yang mutlak dilakukan oleh lembaga legislatif di Indonesia untuk ikut andil mencegah lahirnya undang-undang yang bertentangan dengan peraturan perundang-undangan yang lebih tinggi atau setara atau bahkan bertentangan dengan peraturan perundang-undangan yang setara. Mekanisme yang dapat dilakukan oleh lembaga legislatif ini adalah mekanisme Legislative Preview. Mekanisme pengujian model ini adalah mekanisme pengujian atas suatu peraturan perundangundangan yang belum disahkan menjadi undang-undang. Artinya, pengujian model ini dapat dilakukan atas suatu undang-undang saat masih berbentuk rancangan undangundang atau raperda apabila sudah disetujui bersama untuk menjadi undang-undang atau peraturan daerah. Mekanisme ini penting dilakukan bahkan jauh lebih penting dari tiga mekanisme pengujian yang disebutkan di atas.

Legislative preview dapat mencegah berlakunya suatu undang-undang yang bertentangan dengan kehendak dan logika rakyat. Hal ini terjadi karena sebelum diberlakukan menjadi hukum positif, suatu peraturan perundang-undangan tersebut dapat di uji materi terlebih dahulu oleh lembaga yang membentuknya. Karena lembaga yang membentuk tersebut mengetahui berbagai kelemahan yang ada dalam RUU yang akan diresmikan menjadi undang-undang. Artinya anggota legislatif dapat menguji hal-hal yang dirasa memiliki keganjilan dalam suatu RUU yang akan diundangkan. Anggota legislatif sebagai pelaku sekaligus penguji tentu memiliki kelebihan karena terlibat sejak dari proses awal pembuatan sehingga dapat memahami secara utuh mana pasal-pasal atau ketentuan yang dirasa dipaksakan pada saat pembahasan dan persetujuan. 
Lewat mekanisme Legislative Preview ini maka anggota legislatif memiliki kesempatan kedua untuk melakukan intropeksi atas sikapnya dalam proses suatu rancangan undang-undang menjadi undang-undang atau peraturan daerah. Di sini, para anggota legislatif yang memiliki wewenang melakukan uji materi atas suatu rancangan undang-undang dapat memperbaiki kesalahan yang dilakukan pada saat masih proses pembentukan. Hal ini penting karena dalam proses pembahasan RUU menjadi undangundang amat sangat kental dengan aroma politik ketimbang memperdebatkan subtansi. Oleh karenanya, ketika suatu RUU sudah disetujui dan tinggal menunggu pengesahan dapat diuji materi terlebih dahulu oleh para anggota legislatif. Anggota legislatif dapat menilai apakah pertimbangan-pertimbangan pada saat pembahasan RUU telah sesuai dengan asas dan dasar dibentuknya suatu rancangan undang-undang tersebut menjadi undang-undang. Kesempatan kedua di atas tentu dapat mencegah suatu RUU benar-benar disahkan menjadi undang-undang padahal isi dari undang-undang tersebut banyak mengandung ketentuan yang salah. Bersamaan dengan itulah, ketika RUU yang sedang menunggu pengesahan namun diuji terlebih dahulu oleh lembaga legislatif maka akan menjadikan anggota DPR dapat mencegah lembaganya dipermalukan oleh rakyat. Pasalnya, dengan mekanisme legislative preview, anggota DPR dapat membatalkan ketentuan dalam RUU yang sekiranya menimbulkan kontroversi dan dibatalkan oleh lembaga peradilan. UU yang dimohonkan uji materi kemudian dibatalkan oleh lembaga yudikatif maka DPR atau DPRD dipermalukan oleh rakyat karena membentuk suatu peraturan perundang-undangan yang bertentangan dengan kehendak rakyat.

Mekanisme legislative preview ini dapat mencegah terbitnya suatu undangundang yang justru bertentangan dengan undang-undang yang setara. Terdapat banyak undang-undang yang justru isisnya bertentangan antara undang-undang yang satu dengan 
yang lainnya. Hal ini terjadi karena dalam menyusun suatu undang-undang yang baru, legislator tidak memperhatikan undang-undang lain khususnya undang-undang terkait. Kondisi ini kemudian berakibat pada munculnya tumpang tindih antara peraturan perundang undangan yang baru dengan yang lainnya sehingga saat diundangkan membingungkan pelaksanaan di lapangan. Namun ketika terdapat mekanisme legislative preview maka otomatis suatu rancangan undang-undang yang akan disahkan menjadi undang-undang dapat diuji atau dievaluasi terlebih dahulu singkronisasi isi ketentuan dalam undang-undang tersebut dengan undang-undang yang lainnya sehingga apabila ditemukan adanya ketentuan yang bertentangan dengan peraturan perundang-undangan lainnya maka dapat segera diantisipasi sebelum diundangkan.

Selain itu priview ini juga untuk menghindari lahirnya Hyper regulation. dalam konteks ini adalah banyaknya undang-undang yang tidak penting. Di Negara kita banyak terbit undang-undang yang tingkat kebutuhannya tidak begitu diperlukan. Dan saking banyaknya undang-undang yang diterbitkan menjadikan penyelenggara negara menjadi kaku dalam melakukan penyelenggaraan pemerintahan sehingga seakan akan kewenangan yang dimiliki oleh penyelengara negara menjadi amat terbatas dan cenderung tidak responsif atas situasi dan kondisi yang ada. Banyaknya undang-undang yang diterbitkan seakan mengembalikan negara Indonesia sebagai negara formil bukan negara kesejahteraan.

Hal inilah yang kemudian juga berjuang pada terbitnya sebuah undang-undang yang justru membuat takut penyelenggara negara untuk melakukan tindakan hukum walaupun pada saat yang bersamaan seorang penyelenggara negara harus dihadapkan dengan keharusan untuk mengambil suatu tindakan kongkrit atas keadaan tertentu atau bahkan untuk melakukan terobosan kebijakan. Satu sisi, banyaknya undang-undang yang 
mengatur amat sangat detail tindakan hukum pemerintah menjadi sesuatu yang dimaklumi pasalnya seorang penyelenggara negara juga terikat asas legalitas yakni suatu tindakan pemerintah harus didasarkan atas ketentuan peraturan perundang-undangan dan atau kekuasaan yang dimiliki.

Di sisi berbeda, banyak aktivitas penyelenggara negara yang tidak terakomodir dalam ketentuan undang-undang. Artinya, banyak tindakan hukum sehari-hari penyelenggara negara yang tidak terakomodir dalam peraturan perundang-undangan namun tindakan tersebut tidak jadi dilakukan karena banyak undang-undang yang membatasi ruang gerak penyelenggara negara sehingga penyelenggara negara menjadi takut. Walaupun dalam hukum administrasi mengenal diskresi, namun diskresi sering menempatkan apakah seorang penyelenggara negara harus menggunakan diskresi atau diam pada saat menghadapi situasi tertentu maka seorang kepala daerah lebih cenderung untuk tidak menggunakan diskresi tersebut. Dari posisi sejenis inilah kemudian legislative preview dibutuhkan yakni buat apa menerbitkan banyak undang-undang yang justru menjadikan keadaan di lapangan menjadi kaku.

\section{Kompetensi DPD RI Dalam Mengemban Amanah Undang - Undang Nomor 2 Tahun 2018 Tentang MPR, DPR, DPD dan DPRD Sebagai Lembaga Tinggi Negara}

Tugas pengawasan terhadap pelaksanaan undang-undang tidaklah sederhana, mengingat masih banyaknya peraturan perundang-undangan baik itu dalam bentuk undang-undang maupun peraturan turunan dibawahnya yang belum konsisten dari segi materi pasal per pasal maupun dalam tataran teknis pelaksanaannya. Sehingga perlu dilakukan pengawasan terhadap pelaksanaan undang-undang sebagaimana diatur dalam 
UU MD3. Bahkan dalam penelusuran juga ada indikasi masalah dalam tataran filosofisnya. DPD dalam melakukan pengawasan terhadap pelaksanaan undang-undang akan memastikan bahwa undang-undang tersebut benar-benar efektif dan dapat mengakomodir kepentingan daerah. Undang-undang tertentu yang masuk dalam lingkup UU tertentu meliputi otda, pemekaran daerah, sumber daya alam, dan sumber daya ekonomi, APBN, pajak, pendidikan dan agama. Berikut adalah alur pengawasan terhadap pelaksanaan undang-undang di DPD RI pada Bagan 7 sebagai berikut:

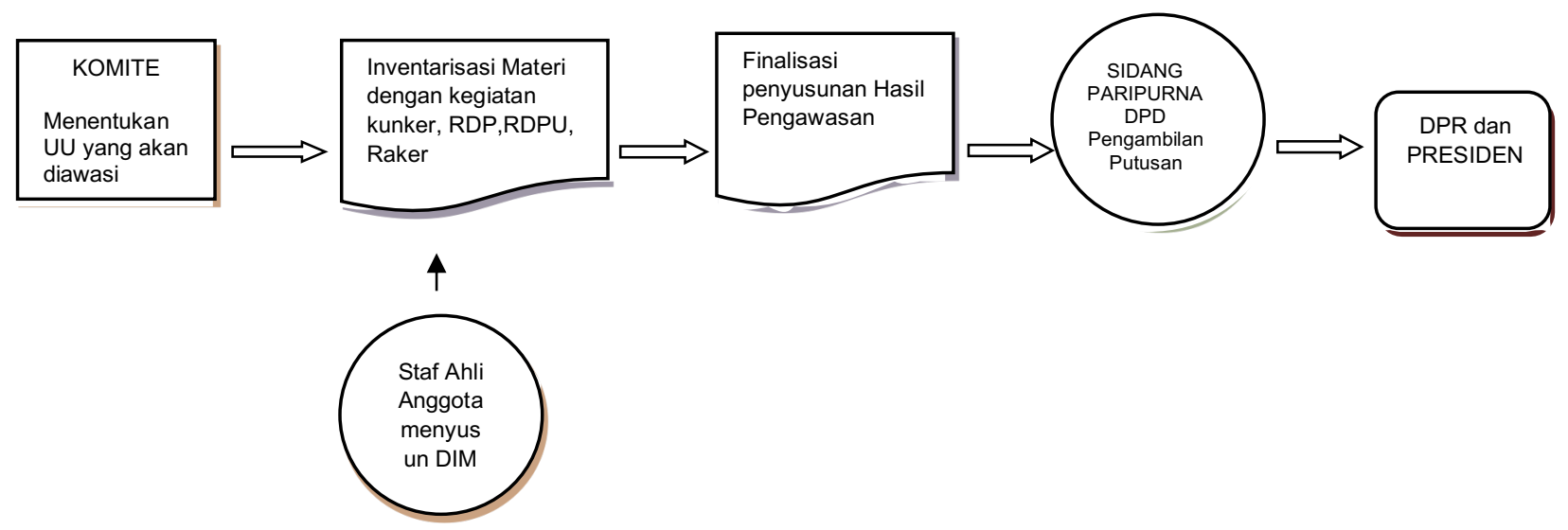

Bagan 1. Proses Penyusunan Pengawasan Terhadap Pelaksanaan Undang-Undang

Sedangkan pemantauan Raperda berdasarkan pada Ketentuan Pasal 249 Ayat 1 huruf j Undang Undang Nomor 2 Tahun 2018 dan Pasal 239 sampai dengan Pasal 241 Peraturan DPD RI Nomor 3 Tahun 2018 tentang Tata Tertib, dapat dilaksanakan secara aktif atau pasif. Pemantauan Raperda secara aktif dilakukan oleh anggota masing-masing di daerah pemilihan untuk melaksanakan kewajiban (Pasal 13 huruf k) dan fungsi representasi. Lingkup Raperda dimaksud meliputi Raperda Provinsi, Kabupaten/Kota, Papua dan/atau Papua Barat, Raperda Khusus Kabupaten/Kota di Provinsi Papua dan/atau Papua Barat, Raperda Khusus Provinsi DKI Jakarta, Raperda Istimewa Yogyakarta, Rancangan Qanun dan Qanun Provinsi, Kabupaten/Kota di Provinsi Aceh. 
Pemantauan Raperda secara aktif dilakukan oleh anggota apabila terdapat informasi bahwa Raperda itu menimbulkan polemik di masyarakat karena berpotensi bertentangan dengan Undang-Undang. Pemantauan ini dilakukan oleh anggota masingmasing di daerah pemilihan dengan melakukan kegiatan pengumpulan data untuk mendapatkan informasi Raperda provinsi, kabupaten, dan kota. Pengumpulan data dilakukan untuk perencanaan penyusunan program pembentukan Perda, penyusunan Raperda, pembentukan Perda, penyusunan rencana strategis daerah dan penyusunan rencana pembangunan jangka menengah daerah. Hasil pengumpulan data itu dibahas dalam rapat anggota provinsi untuk disepakati bersama untuk disampaikan kepada Panitia Urusan Legislasi Daerah (PULD), alat kelengkapan DPD yang membidangi Perda/Raperda. Selain pengumpulan data, pemantauan aktif terhadap Raperda dilakukan juga dengan kegiatan rapat kerja dengan pemerintah daerah dan/atau DPRD provinsi, kabupaten, dan kota, termasuk pemangku kepentingan di daerah, dan kunjungan kerja ke pemerintah daerah dan/atau DPRD provinsi, kabupaten, dan kota, termasuk pemangku kepentingan di daerah.

Pemantauan Raperda secara pasif dilakukan oleh anggota masing-masing di daerah pemilihan atas dasar aduan dari masyarakat, pemerintah daerah (termasuk perangkat daerah) atau DPRD ke kantor perwakilan DPD RI di Ibukota Provinsi atau ke kantor DPD RI pusat di Jakarta. Pemantauan secara pasif terhadap Raperda dapat juga dilakukan terhadap Raperda yang belum ditetapkan atau telah ditetapkan oleh Pemda dengan dibuktikan oleh berita acara penetapan Raperda dan disertai surat pengantar kepala daerah. Hasil pemantauan Raperda baik secara aktif maupun pasif dilaporkan dalam sidang paripurna untuk kemudian disampaikan kepada PULD agar dilakukan evaluasi. 
Evaluasi adalah kegiatan menganalisis, dan mengkaji Raperda dan Perda untuk menjadi bahan rekomendasi (Ketentuan Umum, Pasal 1 angka 18). Evaluasi Raperda dan Perda dilaksanakan oleh PULD setelah menerima hasil pemantauan anggota di daerah. Evaluasi Raperda dan Perda meliputi analisis Raperda dan Perda provinsi, kabupaten, dan kota, yang dilaporkan pada Sidang Paripurna DPD untuk menjadi Rekomendasi. Rekomendasi tersebut disampaikan kepada DPR, Pemerintah Pusat, dan/atau pemerintahan daerah sesuai kewenangannya.

Evaluasi Raperda dilakukan oleh PULD setelah menerima hasil pemantauan secara aktif maupun pasif yang dilakukan oleh anggota di daerah pemilihannya (Pasal 239 ayat (3)). Sebagaimana Pasal 242 Peraturan DPD RI Nomor 3 Tahun 2018 tentang Tata Tertib bahwa evaluasi Raperda dilakukan melalui penelaahan, analisis dan pengkajian terhadap Raperda provinsi, kabupaten dan kota. Dengan kriteria atau identifikasi masalah yang ditentukan dalam Pasal 142 ayat (1) huruf b Peraturan DPD RI Nomor 3 Tahun 2018 tentang Tata Tertib yaitu:

1) kesesuaian jenis, hierarki, dan materi muatan;

2) kejelasan rumusan;

3) pemenuhan asas materi muatan;

4) potensi disharmoni; dan

5) efektivitas implementasi.

Hasil penelaahan, analisis dan pengkajian memungkinkan suatu Raperda yang dievalusi memenuhi dan tidak memenuhi kriteria tersebut. Untuk Raperda yang memenuhi kriteria sebagaimana ditentukan dalam Pasal 142 ayat (1) huruf b Peraturan DPD RI Nomor 3 Tahun 2018 tentang Tata Tertib, PULD mengadakan pembahasan dan klarifikasi dengan pemerintah, pemerintah daerah, DPRD terkait dan pemangku 
kepentingan lainnya melalui rapat kerja; rapat dengar pendapat; rapat dengar pendapat umum; dan kunjungan kerja.

Hasil pembahasan dan klarifikasi berupa laporan tertulis sebagai bahan rekomendasi. Hasil tersebut kemudian dilaporkan kepada Sidang Paripurna DPD RI. Rekomendasi DPD RI tersebut bersifat umum, politis dan strategis berupa: perubahan Raperda, perubahan regulasi, maupun implementasi. Selain itu dapat pula menghasilkan pendapat dan pertimbangan, maupun masukan kepada Pemerintah Daerah.Disisi lain terhadap Raperda yang tidak memenuhi kriteria sebagaimana yang tercantum pada Pasal 142 ayat (1) huruf b Peraturan DPD RI Nomor 3 Tahun 2018 tentang Tata Tertib, proses evaluasi selanjutnya dilakukan oleh PULD dibantu oleh Perancang Kebijakan dan Informasi Hukum melalui pembentukan Tim Asistensi Kesekjenan. Hasil pembahasan berbentuk rekomendasi kesekjenan.

Pengawasan pelaksanaan UU yang dilaksanakan oleh DPD menghabiskan hampir seluruh waktu masa sidang dan reses Anggota DPD. Pada masa sidang, selain pembahasan RUU yang akan diajukan DPD kepada DPR, DPD juga melakukan pengawasan terhadap pelaksanaan UU. Jika beban memantau perda dan raperda akan dilaksanakan secara maksimal, maka dengan rata-rata 2 perda setahun satu daerah maka DPD akan mengurusi tidak kurang dari 1096 perda. Tentu ini akan sangat menguras waktu dan tenaga anggota DPD RI yang harusnya tugasnya bisa maksimal untuk mengawal aspirasi daerah di tingkatan UU.

\section{SIMPULAN}

1. Jika dilihat frasa pemantauan dan evaluasi dalam peraturan perundangan maka konsekuensi dari kewenangan DPD adalah evaluasi yang berujung pada pembatalan 
legislasi daerah. Pasal 22 D ayat 3 menyebutkan bahwa DPD dapat melakukan pengawasan atas pelaksanaan undang-undang. Namun perlu juga dicatat bahwa pengawasan atas pelaksanaan UU bukan hanya berarti mengawasi penerapan satu undang-undang tetapi juga melihat bagaimana satu UU diturunkan secara baik ke dalam peraturan perundangan dibawahnya, termasuk perda. Tetapi Asumsi ini terlalu umum dan terlalu terasa dibuat-buat untuk dijadikan sandaran atas pemberian wewenang pengawasan perda. Karena kalau ini menjadi alasan, maka kewenangan pemantauan dan evaluasi Perda menjadi tidak relevan.

2. Pengawasan pelaksanaan UU yang dilaksanakan oleh DPD menghabiskan hampir seluruh waktu masa sidang dan reses Anggota DPD. Pada masa sidang, selain pembahasan RUU yang akan diajukan DPD kepada DPR, DPD juga melakukan pengawasan terhadap pelaksanaan UU. Dan Jika beban memantau perda dan raperda akan dilaksanakan secara maksimal, maka dengan rata-rata 2 perda setahun satu daerah maka DPD akan mengurusi tidak kurang dari 1096 perda. Tentu ini akan sangat menguras waktu dan tenaga anggota DPD RI yang harusnya tugasnya bisa maksimal untuk mengawal aspirasi daerah di tingkatan UU.

\section{SARAN}

1. Merumuskan kewenangan DPD dalam pemantauan dan evaluasi perda Raperda adalah tugas pertama yang tampaknya harus sesegera dan setepat mungkin untuk dilakukan. Konsep yang salah dan tanggung akan membuat posisi DPD yang sudah terasa hambar dalam bidang legislasi, menjadi semakin garing dengan penambahan kewenangan ini dan melaksanakan Legislataive riview untuk melihat sisi utilitas satu produk perundangan yang dilakukan oleh badan legislasi di satu Negara bisa menjadi 
solusi untuk menghasilkan produk perundangan yang lebih berkualitas. Sekaligus mengurangi tumpang tindih pengujian di lembaga judikatif.

2. Membatasi perda pada tingkatan provinsi dapat menjadi solusi untuk lebih memberikan arah terhadap pemantauan dan evaluasi legislasi daerah oleh DPD. Sekaligus menegaskan territorial yang diwakili DPD adalah pada level provinsi.

\section{DAFTAR PUSTAKA}

\section{BUKU}

Amiruddin dan Zainal Asikin, 2006, Pengantar Metode Penelitian Hukum, Jakarta: PT. Raja Grafindo.

Arikunto, Suharsimi, 2000. Prosedur Penelitian suatu Pendekatan Praktek. Jakarta: Rineka Cipta,

C.F. Strong, 2008. Konstitusi-Konstitusi Politik Modern: Studi Perbandingan tentang Sejarah dan Bentuk-Bentuk Konstitusi di Dunia, Bandung, Cetakan Kedua, Nusamedia,

Hadi, Sutrisno. 1980. Metodologi Riserch 1. Yogyakarta: Gajah Mada,

Law center - PPUU DPD RI, 2017, Peta Jalan Legislasi DPD RI, Jakarta.

Manan, Bagir, 1993. Perjalanan Historis Pasal 18, Karawang: UNSIKA,

PPUU DPD RI, 2017. Legal Drafting untuk Senator, Jakarta.

Sekretariat Jenderal MKRI, 2004. Cetak Biru, Membangun Mahkamah Konstitusi, Sebagai Institusi Peradilan Konstitusi Yang Modern Dan Terpercaya, Jakarta.

Soemitro, 1990. Metodologi Penelitian Hukum, Jakarta: Rineka Cipta,

Soemitro, 1998. Metodologi Penelitian Hukum dan Jurimetri, (akarta: Ghalia Indonesia,

Soekanto, Soerjono, 2014. Pengantar Penelitian Hukum, Jakarta: UI-Press,

Tim Penyusun, 2000, Otonomi atau Federalisme, dampaknya terhadap Perekonomian, Jakarta: Pustaka Sinar Harapan, Harian Suara Pembaharuan,

\section{JURNAL ILMIAH}

Ahmad Siboy, Pengujian Undang-Undang. Malang. Jurnal Negara dan Keadilan.

Manan, Bagir, 2001. Menyongsong Fajar Otonomi Daerah, Pusat Studi Hukum Fakultas Hukum UII, Yogyakarta

Niessen, Nicole, 1999, Municipal Government In Indonesia Policy, law and Practice of Decentralization and Urban Planning, Research School CNWS School of Asian, African, and Amerindian Studies, Universitiet Leiden, The Netheralands,

\section{PERATURAN}

Undang Undang Dasar Negara Republik Indonesia 1945 
Jurnal Yuridis Vol. 6 No. 2, Desember 2019: 1 -32

P-ISSN: $1693-4458$

E-ISSN: 2598-5906

Undang Undang No. 12 Tahun 2011 Tentang Pembentukan Peraturan Perundang-undangan Tata Tertib DPD No. 3 tahun 20018 tentang Tata Tertib.

Undang Undang No. 23 Tahun 2014 tentang Pemerintahan Daerah. 